\title{
1. Introduction to Handbook on Gender, Diversity and Federalism
}

\author{
Jill Vickers, Joan Grace and Cheryl N. Collier
}

In this Handbook a number of international gender scholars explore the third 'wave' of research about gender, diversity and federalism. It focuses on how institutions, ideas and practices affect, and are affected by, gender regimes as well as territorially and non-territorially organized diversities, including minority ethnicities, 'race', religious and sexual minorities. In recent decades, scholarship examining the intersections between gender, diversity and state architectures in federations progressed through several earlier 'waves'. In the first wave, starting in the 1980s, feminist political scientists and legal scholars began exploring if federal systems were good or bad for women in reference to their ability to make claims against the state, usually coming to the unsatisfying conclusion that 'it depends'. Most of these early inquiries referred to older federations, such as Australia and Canada. A second wave of gender/federalism research started around 2000. Building on earlier inquiries, feminist scholars of federalism explored if and how federal systems were gendered and what this means for women's advocacy, organization and citizenship. But they often failed to recognize the changing natures of federations and how actors such as women's movements can reshape architectural arrangements and institutional opportunities.

Contributors to this Handbook use various approaches to study how gender and diversity interact with different manifestations of federalism, drawing on earlier texts about how organized women increased their political participation, representation and ability to hold governments accountable. Drawing from federalism studies and 'women, gender and politics' research, Handbook contributors explore how state architectures and processes, including inter-governmental relations (IGR), interact with activists' pursuit of security (protection from violence), autonomy (access to safe abortion, reliable contraception, child care, education and occupation) and freedom (gender and LGBTQ rights and human rights). Other contributors explore how gender and diversity facets of major issues such as health care affect benefits for minority 'races' or ethnicities and issues of conflict management, including between religious and gender rights.

While this collection is not a complete survey of the gender, federalism and diversity field, the diverse contributions provide a good overview of its current state. Some Handbook chapters study how federalism and gender regimes] interact and conceptualize 'federalism' both as a philosophy of governance and a way of organizing a state with multilevel governance (MLG). Most contributors build on the theoretical insights and empirical findings from earlier research waves including approaches in which 'gender' is the main analytical variable. Others study relations between federalism and 'diversity' generally, including gender, 'race', sexual orientation, ethnic and religious minorities. About a third of the chapters explore gender and diversity in federations in the global south (Latin America, Asia, Africa), revealing important lessons about differences from 'western' federations (Europe, North America, Australia) that often were the sole subject of earlier research waves. Consequently, the Handbook offers new 
insights into interactions between gender or diversity and de/colonization, federalization, de/ centralization and democratization. Some chapters provide insights into how federalization and democratization reflect colonial origins and experiences with the subsequent effects of decolonization and military or authoritarian rule which results in overcentralized institutions.

The Handbook's development of third-'wave' gender/federalism research builds on the issues, goals and approaches drawn from earlier waves. Some chapters explore how federal structures and gender regimes interact in western federations like the United States (US) and how organized women experience federalization when they mobilize for gender equality. Early gender/federalism research explored women's politics in 'old' federations shaped by their founders' choices of federal governance. Some also worked to 'hold together' stressed unitary countries like Belgium; or compound polities like the United Kingdom in which power has been devolved to regional bodies. There also are 'hold together' cases like Spain in which Catalonia provides new insights about how national minority and gender activists interact with MLG.

Most gender scholars, like mainstream federalism researchers, believe that only democratic federations are authentic and, therefore, exclude socialist federations (notably the Soviet Union and Yugoslavia) and federations under military or authoritarian rule. But in some such cases, MLG plays an important role in democratizing the polity with regional governments serving as platforms for competing parties to challenge the dominant party thereby sometimes ending authoritarian rule and promoting democratic change. Third-wave gender/federalism research is also beginning to explore intersectional diversity beyond 'gender' and is including 'race', ethnicity, language, religion and minority sexual status in its analyses. New themes are emerging from research about federations in the global south, notably about the impact of de/ colonization and democratization on gender regimes following authoritarian rule.

This introduction compares static and dynamic approaches to gender/diversity interactions with federalization and explores how de/colonization has affected democratization. Dynamic approaches also are conceptualized as adaptive or evolutionary. As mentioned, early 'waves' of gender/federalism research were limited to studies of western countries as gender scholars tried to understand if federal arrangements had positive or negative outcomes for women seeking equality rights. But they generally ignored the impact of de/colonization or democratization, although many western federations began as British colonies. Nonetheless, the elites shaping these older federations chose federalism which, by contrast, was usually imposed on federations in the global south. Moreover, most early research conceptualized federalism as a static system of powers framed within a rigid constitution. This captured bargains to which founding elites agreed and encapsulated constitutionally defined competencies in static snapshots. Because gender scholars must promote change to achieve equality and resist formal, static structures they tend to use concepts like informal institutions to promote change. Consequently, third-wave research focuses on the dynamic aspects of federalization, including de/centralization. This is especially evident with gender/federalism scholars studying the global south, who more often explore how these dynamic aspects of federalization, de/ colonization and democratization affect gender regimes. Third-wave federalism researchers are starting to pay attention to other aspects of diversity, many of which are explored in this Handbook.

Gender and politics scholars have tended to assume that organized women seeking equality always and ideally relate to unitary states, ignoring the impact of state architectures, notably federal arrangements. With $25+$ federations, including the world's largest and most powerful states, there is a disconnect between the unitary state bias of the earlier 'gender and politics' 
field and the increased growth of states with MLG and those utilizing 'federal arrangements'. Some contributors to this volume address this disconnect illustrating the importance of research about the dynamic aspects of federalization, especially in the global south given the impact of colonization. Federalization also occurs in countries that aren't formal federations but use some 'federal arrangements' to accommodate diversity and manage conflict. Stockemer and Wigginton's chapter compares the effects of a full federation on women's representation compared to the effects of partial federal arrangements in unitary states like China. Henders' chapter shows how having some federal arrangements in Hong Kong affects women's representation and participation. Vickers' chapter explores new IGR typologies that facilitate comparisons of countries with both full and partial federal arrangements.

New issues being explored by Handbook contributors also include those drawn from both the 'gender and politics' and the 'gender/federalism' literatures, often investigating aspects of 'diversity' other than gender. To date many aspects of diversity have been under-represented, including the question of how federalism interacts with 'race' (for exceptions see Miller 2008; Vickers and Isaac 2012). For example, the growing literature about the disappearance and death of Indigenous women in federations deserves its own volume and is not fully addressed here. Chakraborty, Nayyar and Jain's chapter, however, discusses gender budgeting as a policy innovation with the potential to transcend various diversities in India. Spary's chapter examines how the 'federalism advantage' may benefit diverse women, especially in federations in the global south. Further, Haussman's contribution about how Trump's 'Principles of Economic Mobility' affect women and other Medicaid recipients including those of minority 'races' highlights some intersectional aspects of 'gender'/'race' interactions. Several chapters explore interactions between federalism and LGBTQ rights and conflicts between 'gender' and religious rights. Miriam Smith's chapter offers in-depth research about US campaigns for LGBTQ rights and builds on her second-wave research that compared the Canadian and US federations. It showed how activists used Canada's distinct federal system to obtain LGBTQ rights before the US - notably same-sex marriage rights. Peter (Jay) Smith's chapter exploring conflict between gender and religious rights is especially innovative because it compares federations similar in type but distant in location - Canada/Quebec and Nigeria.

About a third of the Handbook's chapters explore gender politics in federations in the global south that experienced post-colonial and military or authoritarian rule. The chapter by Dayil and Vickers, for example, focuses on how the post-colonial Nigerian government has managed (or mismanaged) the provision of security for women and girls after long periods of military rule and during periods of democratization. Similarly, Bohn's and Beer's chapters explore the limited ability of the Brazilian and Mexican states to provide security for women and girls. But Anctil Avoine and Viens' chapter suggests that federal structures may help solve the problems of gender-based violence in India. The effects of 'de/colonization' need conceptualization and definition while using a gender/federalism lens to understand democratization in the global south which gender scholars usually attribute to economic development. A key question is: does federalism reproduce power structures that remain inherently colonial and gendered? The research for these chapters shows that one outcome of colonial and military or authoritarian rule in federations is the overcentralization of power in central governments - a legacy shared by many federations in the global south. Third-wave 'gender/federalism' research explores diverse patterns of de/centralization. In most western federations, the dominant pattern is centralization; however, multinational federations like Canada tend toward de/centralization and adopt 'opting-out' mechanisms in their conflict-management strategies. 
Federations in the global south experienced de/colonization and military or authoritarian governance alternating with democratization and decentralization. But Mufti's chapter about constitutional decentralization in Pakistan suggests that the reserved seats designed to increase women's representation in local government also reflect elites' desires to undercut regional competitors as much as to advance democratization. Some third-wave researchers explore the dynamic processes involved in federal decentralization theorizing that its main drivers are 'modernization' - notably, the socio-economic and socio-cultural trends that affect regional units' autonomy and the production of diverse outcomes across policy fields. This third-wave research also focuses on interactions between federalization and democratization across contexts. It shows that federal arrangements in reality aren't static and formal constitutional amendments aren't necessarily needed to achieve change.

\subsection{EVOLUTIONARY APPROACHES AND ADAPTIVE FEDERALISM}

Early scholars in the first two waves of gender/federalism research imagined the division of powers as 'layer cakes' with rigidly assigned competencies framed in hard-to-change constitutional categories. But many third-wave gender/federalism scholars use the concept of informal institutions to make such static approaches more dynamic, as Grace does in her chapter in this Handbook. A more dynamic approach was needed by organized women who focused on change to promote gender equality. This move toward a more dynamic approach started in the second wave of research but is dominant in the third wave. Arguably, the greater presence of more dynamic third-wave approaches is the most significant difference typified by increased comparisons that include federations in the global south. Scholars like Máiz et al. (2018) reject traditional approaches in part because they are static, but also because they are reductionist; that is, preoccupied with legal 'closure' and keen to impose a 'ceiling' on decentralization. Advocates of more dynamic approaches maintain that a 'robust federation is flexible, not rigid' (Bednar 2008, 15). Vickers' chapter summarizes the value of more dynamic approaches drawing on Elinor Ostrom's theory of federations as polycentric.

'Adaptive' or 'evolutionist' approaches conceptualize federations as 'indeterminate and contingent political processes, rather than structures crystallized once and for all' (Máiz et al. 2018,498 ). Further, they see a federation as 'a complex adaptive system... a political system endowed with a... capacity for experimentation and variation in time and place' (Máiz et al. 2018, 498). Federal arrangements involve 'a complex and changing set of rules, laws, values and behaviours... constituting an interaction which, from an evolutive perspective, prevents conceptions of a federal system through the ontological fallacy of the simple sum of its constituent parts' (Máiz et al. 2018, 497). When federations in the global south are included in comparisons, they take different forms and use a variety of designs, mechanisms and practices (Watts 2000) to make them adaptive. Evolutionary approaches conceptualize federalization as a dynamic process proceeding through gradual institutional change which creates systems with varying degrees of flexibility and ambiguity. But federalization may be partial as when unitary states borrow federal mechanisms to help manage conflicts resulting from territorially manifested diversity. But politics, negotiations, violent interactions and even civil wars also can be aspects of federalization especially when imposed by a departing colonial power. 
In Spain, most discussions of federalism embrace a dominant static, reductionist discourse as outlined in the Spanish Socialist Workers' Party's (PSOE's) Declaración de Granada (2013) which features a rigid structural vision of a federation with an unchanging distribution of competences and limited decentralization. Máiz et al. $(2018,497)$ borrow the concept of adaptive federalism (Bednar 2009; 2011) to signify the resilience of federations and their ability to 'address diverse circumstances, changes or crises' which they conceptualize as a 'stratified and over-lapping set of rules, laws and actors that, the product of a continuous evolutionary progress, is never completely sutured'. Moreover, evolutionary approaches offer dynamic perspectives open to both change and contingency.

\subsection{APPROACHES TO DE/CENTRALIZATION}

The most common approach to de/centralization theorizes several socio-economic and socio-cultural drivers of 'modernization' including technological change, increased mobility and market integration, all of which are thought to centralize government. International rights treaties also increase centralization, as do increases in citizens' expectations about governments' roles. In particular, citizens' demands for uniform welfare services across the country also are thought to promote centralization. Another perspective is that the distribution of powers in federations presses towards centralization. But while the mainstream literature assumes a common trajectory toward centralization there are exceptions, like Canada, in which decentralization prevails. Trajectories toward de/centralization vary according to the type of federation involved: for example, mono-national federations are more likely to follow the centralization trajectory; whereas multinational federations like Canada are more likely to pursue decentralization (see chapters by Grace and Vickers). Nonetheless, some apparently multinational federations like Switzerland that manage to forge a common national identity also follow the trajectory for centralization just like their mono-national counterparts. However, both levels of centralization and decentralization also can be affected by partisan variables; for example, older 'western' federations with right-wing regimes are more predisposed to decentralization than those with left-wing governments (see Collier's chapter). One hypothesis about what drives dynamic centralization is that the scope of government in old federations increased during the nineteenth and twentieth centuries because of changes in citizens' expectations of their governments. But for many federations in the global south, de/ colonization and military or authoritarian rule created different trajectories. Colonial power, de/colonization, military or authoritarian rule all involved highly centralized governments that conflated democratization and decentralization rather than 'modernization' theories as developed in western federations in the nineteenth and twentieth centuries. However, to date there has been little research about how such de/centralization affects gender regimes. Observing the impact of decentralization on post-colonial, multinational federations shows the importance of including experiences regulated by family law, in analyzing de/centralization's impact, notably marriage, adultery and divorce. Moreover, this is true for both older western federations and newer federations in the global south (see Rubenstein's chapter).

As an internal subject nation, Catalonia differs from polities that were former colonies, however, under Franco's rule, it was subject to military or authoritarian rule from Madrid. The result was a regional state whose elites are keen to be part of a decentralized federation or to secede with their own central state. Australia and Canada both drew together groups 
of colonies whose leaders chose to form federations. This was somewhat in imitation of the US which also brought former British colonies together; but while the American colonies rebelled and gained their independence through war, Canada and Australia gained home rule without war while also choosing to be federations. Both federal state structures and the new US congressional form of government formed a template imitated by some other newly independent states, especially in Latin America. So, while these older federations were all made up of former colonies, federalism was a choice and not imposed on them. But except in Australia, women were excluded from the public sphere for some time after independence (see Rubenstein's chapter). By contrast, the newer British colonies in Asia and Africa experienced federalism as alien and imposed. Nationalists resisted federalism but ultimately it was accepted as part of the price of independence. So, federalism wasn't 'a colonial legacy in India, Pakistan or Malaysia... [where] nationalists] seeking independence rejected plans based on federalism' (Bhattacharyya 2010, 21). There was no pre-colonial tradition of federalism 'as a political principle of governance' in these countries. So, 'the development of federalism... remained enmeshed with colonialism, anti-colonial nationalist movements and post-colonial experiments with democracy and nation-building' (Bhattacharyya 2010, 21).

The three original Asian federations and Nigeria have these things in common: federalism was imposed on them by Britain as a method of effective political control; they also are very diverse polities with high levels of ethnic conflict requiring special methods of conflict management. For example, both India and Nigeria have large Muslim minorities, and both Nigeria and Pakistan experienced long periods of military rule with highly centralized state powers tested by partition, secession or civil war. In the post-colonial period, revised forms of federalism became linked with democracy, most consistently in India but formally and more haltingly in Pakistan, Malaysia and Nigeria. According to Bhattacharyya (2010, 21), 'this... made all the difference in the success or failures of federalism in these countries'. The failures of 'socialist federations' (notably, the Soviet Union and Yugoslavia) supported the western idea that only democracies are authentic federations - and vice versa. However, the ethnically diverse Russian federation involves a flawed, but not liberal democracy which is not explored in this Handbook. Therefore, it is important to examine relations between federalization and democratization after military, authoritarian or socialist governments have been in power. Latin American federations (Argentina, Brazil, Mexico, Venezuela) were formed early and were influenced by US federalism. Their long periods of military or authoritarian rule shaped each federation's institutions, ideas and practices, delaying democratization 7 and offering no opportunity for women's citizenship.

\subsection{GENDER, FEDERALIZATION AND DEMOCRATIZATION}

Most early-wave research assumes that federations are liberal democracies, but pays little attention to the processes of democratization or federalization. This results in the exclusion of non-democratic federations from comparisons, despite the important role federal structures play in transitions from military or authoritarian regimes to democracies. Although 'military rule is antithetical to the concept of federalism' (Seun Akin Yemi cited in Bhattacharyya 2010,21 ), formally they often coexist. Moreover, transitions between military or authoritarian governments and democracies are more fluid and occur over longer periods of time than is assumed by classic federalism theory. Failure to consider the dynamics of emerging feder- 
ations results in them being considered purely the product of founders' wills illustrated in constitutions. But instead of perceiving change as always occurring formally, 'evolutionary' approaches conceptualize more subtle, dynamic and informal mechanisms that 'strategically leave open conflictive questions' (Máiz et al. 2018, 499). This section explores how gender and diversity relate to democratization and federalization.

Democratization involves processes through which authoritarian polities are transformed into democracies, including conditions needed for transitions from the breakup of empires, the liberation of colonies and democracy's deepening through the expansion of citizenship. How are gender regimes affected by interactions between democratization and federalization? In a study of 140 countries over three decades, Udi Sommer (2018) explores relations between democracy and 'gender' conceptualized in terms of demography. Most research on how demography and democracy relate focuses on male political behavior, notably how large cohorts of young men facilitate violent mobilizations (see Dayil and Vickers' chapter). By contrast, Sommer theorizes that declines in fertility rates correlate with democratization, but previously there was little systematic study about how such changes affect democratization. Research on relations between gender and democratization focuses on increases in women's life expectancy, declining rates of infant mortality (Przeworski et al. 2000) and declining fertility rates. Sommer theorizes four mechanisms that mediate how declining fertility rates affect democracy: 1) changes in family structure; 2) changes in women's economic circumstances; 3) women's increased political empowerment; and 4) land policy with better outcomes for women. Since World War II, there have been several significant demographic transitions: a global decline in average fertility from 5.05 in 1950 to 2.49 in 2015; and in the less developed countries, an average decline from 6.22 in 1950 to 2.62 in 2015 (Sommer 2018). When controlled for by the traditional predictors of democracy, Sommer finds 'a highly significant' and 'substantively meaningful' statistical relationship between declining fertility rates and the development of democracy. In countries with high fertility rates, fewer women participate in politics, especially in leadership positions. Lower fertility rates mean women no longer need so many children as insurance for their old age, are likely to have their first child later and so have more time for education. More egalitarian family structures result, creating time and opportunities for women to participate in politics, organize around issues that matter to them and undertake leadership roles.

The term federalization originated with legal scholars who used it to refer to the growth of federal jurisdiction over a field of law. But in her research into how 'race' interacts with federalism, Lisa Miller (2008, 201, note 8) explains that: 'I use the term [federalization] more broadly... because it provides a valuable framework for research across a range of policy issues' (see also Vickers and Isaac 2012). Other gender/federalism scholars use the term to frame the process of founding federal institutions, developing them and federal ideas and practices. How did democratization and federalization affect gender regimes? Most political theorists assume the formation of unitary nation-states more or less naturally followed decolonization and the breakup of empires. But about 40 per cent of the world's population lives in federations and democratization may precede or follow federalization. Especially important is what happens in federations during transitions from military or authoritarian regimes to democratization: for example, between the Mexican Revolution (1810) and when democratization began (2000). The federation was ruled by a series of authoritarian regimes making its government more centralized than any other federation (Beer 2017, 2). Democratization initi- 
ated decentralization and often also involved transitions from single- to multi-party elections, MLG and deepened democratic culture.

The main question that preoccupied western gender scholars of the early waves of research was, would 'federalizing' issues across legislative venues enhance or diminish democracy? In fact, federal arrangements facilitated democracy on a large scale for the first time; while the previously largest (territorial) polities were empires that didn't facilitate democracy. Gender scholars now ask insightful questions about the impact of federalization on women's political participation. Most unitary polities are organized in a hierarchical pyramid with levels of government based on more or less authority; so too are federations that are overcentralized because of colonial, military or authoritarian rule. But other federations are polycentric; that is they lack a single center, as Vickers argues in her chapter on IGR. So, despite the fact that there are just roughly 25 federations globally (depending on how strictly 'federation' is defined), many have very large populations. Indeed, seven of the world's eight (territorially) largest countries are federations.

Federal arrangements can be used by territorially concentrated minorities to achieve meaningful autonomy within formally unitary polities. Henders' chapter about Hong Kong's relations within China explores how the 'one country, two systems' arrangement affects women's rights and participation. Therefore, there are cases with federal arrangements within unitary states with unique impacts on women's political representation and advocacy opportunities. Further, in some otherwise democratic federations such as Mexico, there may be one or several authoritarian regional states.

Relations between gender regimes and democratization depend on the age and type of the federation. In 'old' federations founded in the late eighteenth or nineteenth centuries, women were viewed mainly as private dependents, not as citizens (Ritter 2006). Moreover, allocations of legislative powers generally followed an imposed public/private split between the central governments (public) and their regional (private) counterparts. In the US, for example, women weren't considered eligible for the protections of the Bill of Rights or the Fourteenth Amendment (Ritter 2006) until they became active in the public sphere and were considered public persons. Instead, their protection was considered a private matter, with the state not expected to protect them. The first case in which women acted as, and were considered, public persons and full citizens was when Australia federated in 1902. A feminist founder Rose Scott (Allen 1994) expressed concern over the private/public split of legislative power which assigned family law to the regional states but virtually no powers over welfare issues to the central government. Indeed, this would prove to be problematic for Australian women (Rubenstein 2006) with some problems still persisting (see also Rubenstein's chapter in this Handbook). In federations formed in the twentieth century, women were more often seen as public persons, but still were politically marginalized alongside other 'diverse' groups.

A key question present throughout the first two waves of research and persisting into the third wave for gender/federalism researchers is whether women have been advantaged or disadvantaged by federal arrangements. Contributors Kerri Froc, Linda White, Joan Grace, Cheryl Collier and Miriam Smith offer nuanced explorations of this question in diverse policy areas including assisted reproductive technologies, family and social policy, Indigenous reconciliation and LGBTQ rights. One issue explored is if changes in federal arrangements open up more opportunities for women to participate as legislators. Stockemer and Wigginton's chapter explores quantitative evidence that federations have higher levels of women's rep- 
resentation in central governments, although this declines in cases where unitary states borrow some federal arrangements.

Miller $(2010,175)$ theorizes that while '[f]ederalism may provide multiple pathways of access... it also divides and conquers, isolating poorly resourced groups from one another and making it difficult for them to hold legislators accountable to their interest'. This limits women, most of whom lack resources, to venues close to home that often are inhospitable to their interests. Moreover, organized women face multiple veto points and are otherwise disadvantaged because fragmented federal systems isolate potential allies from one another. Writing about the impact of federalism on feminist projects in Australia, Rubenstein (2006) stated that while feminism and federalism appear to be at odds, when women's interests are not just understood as territorial in nature, they share important features, notably support for diversity and pluralism.

Probably the most important issue explored in the Handbook is protection from violence which feminist advocates lobby for in federations like Brazil as in Bohn's chapter; in Mexico as in Beer's chapter; in India as in Anctil Avoine and Viens' chapter; and in Nigeria as in Dayil and Vickers' chapter. Of course, violence against women (VAW) is not just a problem faced by women in the global south. For example, the Report of the UN Special Rapporteur on Violence Against Women in Canada (2019) asserts that federalism must not be allowed to be a barrier to women's human rights, especially to their security. The rapporteur called for legal reforms to harmonize laws about VAW and 'domestic violence' in all provinces and territories and to ensure that all women and girls (especially in Indigenous and minority races, ethnic and faith communities) have necessary services to protect them from violence wherever it threatens. But as with many other issues, the diversity produced by federations' multiple jurisdictions often results in competition among governments with a variety of solutions and policy innovations. Yet to realize the advantage of such diversity and competition, it is essential that the same basic rights are guaranteed for all women and girls wherever they live. Therefore, the contributors to this Handbook are mapping a research agenda for the future, the outcomes of which will contribute to the 'gender and politics' field, to federalism scholarship and to comparative politics generally.

\subsection{APPROACHES AND METHODS}

In the first two waves of gender and federalism research, the dominant approaches were qualitative; that is, they involved descriptions of policies and issues in single federations alongside 'thick' comparisons. Among the innovations in the third wave of research is the use of quantitative methods and mixed methods. Initially, there were four main approaches to qualitative research in which concepts, categories and hypotheses are 'gendered'. They are:

1. reading women in by asking 'where are women?' and inserting data about how historical legacies, social forces and institutional arrangements affect and are affected by women's experiences and gender regimes;

2. reading against the grain which uncovers insights about women's activities in mainstream texts by making them visible;

3. reading 'gender' in which uses gender analysis to reconceptualize accounts that are facially gender neutral; and 
4. developing new gender concepts and inserting them into the analysis, thereby challenging traditional orthodoxies.

Such approaches facilitated gendered comparisons of federations over time and place. But explaining the dynamics of change such as how early manifestations of IGR become institutionalized requires more systematic qualitative comparison across multiple federations of diverse types. In turn, this requires the operationalization of key concepts, interactions and relationships and, if successful, they also can be quantified.

In this Handbook, contributors use a variety of methods, theoretical frameworks and approaches. These include both qualitative and quantitative approaches, comparative analyses, political economy frameworks, counter-factual analyses and the use of diverse theoretical concepts such as polycentrism, global federalism and nested newness, along with chapters that apply approaches to political analysis such as rational and historical institutionalism and feminist institutionalism.

\subsection{IN THIS VOLUME}

This Handbook is divided into three sections. Part I, Theoretical and Comparative Approaches, begins with Chapter 2 in which Jill Vickers undertakes a comprehensive analysis of IGR across a wide array of federations. Using Ostrom's polycentric lens, she theorizes that as conflict between central and regional governments declines, the institutionalization of IGR increases. In Chapter 3, Linda White explores why Canadian family policies tend to be less generous than in other Organisation for Economic Co-operation and Development countries. White argues that both federalism and a strong liberal welfare tradition encourage private and market-based approaches to care. In Chapter 4, Peter (Jay) Smith compares northern Nigeria and Quebec to explore what has happened in an era of increasing religious intolerance and legal pluralism. He argues that federal systems offer certain advantages to protect human rights. In Chapter 5, attempting to understand variations in women's descriptive representation in legislatures, Daniel Stockemer and Michael Wigginton pose and answer the question of whether central legislatures in federal states have higher percentages of women's representation than in unitary states. In particular, their quantitative analysis opens a new approach to issues such as representation and quotas. In Chapter 6, Judit Fabian grapples with problems of global governance in relation to international relations and security, trade and finance. Because such problems have become increasingly global as the world's population is more interconnected, Fabian theorizes that global federalism may offer insights about how to advance gender justice effectively. Cheryl Collier's study of the National Action Committee on the Status of Women in Canada and the National Organization of Women in the US in Chapter 7 concludes this section. In her comparison of these 'national' (that is, country-wide) organizations, Collier argues that while decentralization is generally unfavorable to organized women's groups, the National Organization of Women fared better in the face of change largely because of its decentralized organizational structure based on dues and donations rather than government support.

In Part II, Third Wave Gender/Federalism Research in Some 'Western'Federations, Miriam Smith (Chapter 8) presents a compelling argument about relations between state architectures of federalism in Canada and LGBTQ movements, especially the role of courts in activism and 
policy-making. In Chapter 9, Kerri Froc also examines courts and judicial decisions with specific attention to a comparison between federalism doctrines in Canada and the US. She argues that in Canada, the division of powers is not necessarily more feminist than in the US. Unlike the US federalism doctrine, however, Canadian courts haven't uniformly assigned women to the private sphere and legislation for their protection nor as local matters with no national or cross-state implications. In Chapter 10, Melissa Haussman explores changes to social welfare policy by examining Medicaid policy debates in the US, analyzing outcomes of differing political priorities under former Clinton and Obama administrations in comparison to the current federal government under Trump. In Chapter 11, Beverly Baines examines three organized campaigns to constitutionalize women's rights in Canada and Quebec, stressing how those campaign narratives submerged diverse gendered identities. In Chapter 12, Tània Verge and Alba Alonso reflect on devolution in Spain, investigating how MLG shapes reforms that recognize women's and LGBTI people's rights. In Chapter 13, Joan Grace argues that IGR, specifically executive inter-provincialism, constitutes a strategic site for gender and federalism research. This involves analyzing the Council of the Federation's critical role in shaping opportunities and obstacles of women's policy advocacy in Canada. Kim Rubenstein's contribution in Chapter 14 rounds out this section by examining the Australian constitutional system starting from feminists' role in the country's adoption of a federal system and considering what this has meant for federalism and feminism scholarship.

Part III, Third-Wave Gender/Federalism Research in the Global South: Latin America, Asia and Africa, completes the Handbook with nine chapters about federations in the global south. The first three focus on Latin American federations. In Chapter 15, Debora Lopreite explores women's policy agencies in Argentina and the impact of IGR in relation to women's right to access safe abortions and contraception. In Chapter 16, Simone Bohn explores the dilemma of achieving gender-friendly policies in uneven federations like Brazil. Bohn considers the efforts of women's movements to compel governments to act on legislative efforts to curb VAW. Caroline Beer investigates how federal institutions in Mexico have shaped women's policy agencies in Chapter 17. Beer demonstrates how Mexico's complex, multisystem array of women's policy agencies influences gender policies.

The final six chapters focus on gender and federalism in Asia and Africa. In Chapter 18, Mariam Mufti compares local government structures in Pakistan to consider if its new institutional arrangements under recent constitutional reforms and devolution have resulted in favorable and secure environments for women. In Chapter 19, Carole Spary investigates the 'federalism advantage' in India. She examines how state architectures and innovations at the regional (state) level which the central government sometimes reproduces, may successfully facilitate the engagement of women's movements with various levels of government. In Chapter 20, Lekha Chakraborty, Veena Nayyar and Komal Jain challenge the 'invisibility' of the care economy within the political economic framework. They discuss the potential value of gender budgeting as a way of empowering women in India's multilevel federal system. Also analyzing India's multilevel system in Chapter 21, Catherine Viens and Priscyll Anctil Avoine tackle the entrenched structures of oppressions women often face despite the existence of the 2013 Rape Law. These three chapters dealing with gender/federalism in India provide special opportunities for exploring relations between federalization and democratization.

The last two chapters deal with two important, dynamic movements, one of which is very contemporary. In Chapter 22, Susan Henders explores the effects of British-era legacies in Hong Kong. While she finds that the autonomy arrangements negotiated initially were benefi- 
cial for women, relations are now troubled since being subsumed under Chinese rule. Finally, in Chapter 23, Plangsat Bitrus Dayil and Jill Vickers explore the \#Bring Back Our Girls movement in Nigeria in relation to the Boko Haram terrorist movement. In their analysis, they theorize that the 'overcentralization' of the central government that resulted from long-time colonial and military rule hampered current governments' capacities for providing security for women and girls.

\subsection{FOURTH-WAVE RESEARCH AGENDA}

\subsubsection{Gender, Diversity and Intersectionality}

A key feature of third-wave gender and federalism research has been the broader range of federations included, the increased consideration of intersectionality, the impact of multiple diverse identities, and their relationships to federal state structures. In the older federations, federal arrangements were often chosen to satisfy diverse representational needs from populations with territorial identities, including minority nations and ethnicities, such as Quebec and Nunavut in Canada. But federalism is less effective in facilitating the representational needs of diverse, non-territorial populations such as Indigenous communities. Many researchers have been drawn to consider the impact and utility of MLG institutional structures for diverse populations inside federations. But much remains to be explored through intersectional frameworks, notably questions about 'nested' or combined diversities across and among people affected by the politics and policies from federal systems.

At first, early gender and federalism researchers questioned how federal architectures impacted women's political access and ability to secure policy gains from the state. While this research mostly recognized that women are not a monolithic group, it usually avoided addressing intersectional issues and diverse identities in any depth. But in the third wave, gender scholars have started probing this intersectionality to get a better sense of the nuance of relations between MLG structures and disadvantaged or marginalized groups in society. This expanding research agenda is evident in studies of Quebec feminists who successfully engaged with the provincial government, leveraging intersectional Quebecoise nationalist and gender identities - an intersection absent at the central government level and unavailable to francophone women outside Quebec. Peter (Jay) Smith explores the complex relationship of gender and religious minority identities in his comparative study of gender and religious conflicts in Quebec and Nigeria. Smith's chapter raises important questions about how federal structures impact diverse feminist interests that don't easily align. In her chapter, Beverley Baines uses an intersectional approach to highlight how campaign narratives subsume multiple identities (multicultural, indigenous and intercultural) and how they were affected by Section 28 of the Canadian Charter of Rights and Freedoms. The fourth-wave research agenda will undoubtedly expand on exploring intersectionality along these lines and beyond.

\subsubsection{Comparing Gender, Diversity and Federalism}

A second important area in the fourth wave of gender/federalism research will expand our knowledge of federations in the global south. This is emerging from countries that have experienced socio-economic and cultural upheavals after military or authoritarian rule as in South 
Africa, Venezuela and China/Hong Kong. More needs to be understood about diversities in multilevel, federal or de/centralized countries, especially those currently understudied by gender/federalism researchers. Another aspect of the agenda for the fourth wave of gender/ federalism research will involve knowledge derived from comparisons between federations in western democracies and those in the global south. Such comparisons will produce important insights and perhaps even new ways of promoting gender equality as well as achieving productive institutional restructuring of federal systems. They will certainly involve the use of frameworks and ideas introduced by contributors to this Handbook, such as Judit Fabian's use of global federalism as a new conceptual pathway.

\section{NOTES}

1. There are several ways of defining a 'gender regime', but for our purposes, it can be understood as a particular set of relations among the sexes in a particular place and historical context. Several regimes usually coexist in a country and period.

2. 'Federalization' is a concept mainly used in legal studies. But Miller (2008) also applies it to policy issues and institutions. We follow her more dynamic approach.

3. Dardanelli et al. 2019. Note that all eight authors are men and gender is not considered in the text.

4. M.A. Jinnah, the founder of Pakistan, was an important exception who favored federation as a way of gaining as much autonomy for Pakistan as possible.

5. Malaysia is a multiparty democracy in which, nonetheless, the central government has been controlled by a single party from 1957 to 2018, when a peaceful transition of power to an opposition party occurred. Because ethnic Malays are a bare majority in Malaysia, the governing Malay-nationalist party mobilized Malay women in its support. But Malaysia's head of state is a 'Supreme King' selected by rotation from among the nine sultans who lead the Muslim-majority Malaysian states. Muslim women are subject to the Shari'a courts that coexist with English common law, but legal pluralism legislated alternate gender regimes for the larger minorities ( $\mathrm{Ng} 2012)$.

6. For a gendered examination of the Russian Federation see Chandler 2010.

7. A key text in English is Gibson 2004. However, it completely ignores women and gender regimes.

\section{REFERENCES}

Allen, Judith A. (1994), Rose Scott: Vision and Revision in Feminism, Melbourne: Oxford University Press.

Bednar, Janna (2008), The Robust Federation: Principles of Design, Cambridge: Cambridge University Press.

Beer, Caroline (2017), 'Making Abortion Laws in Mexico: Salience and Autonomy in the Policy Making Process', Comparative Politics, 50 (1), September, 41-59.

Bhattacharyya, Harihar (2010), Federalism in Asia: India, Pakistan and Malaysia, London: Routledge.

Chandler, Andrea (2010), 'Women, Gender and Federalism in Russia', in Melissa Haussman, Marian Sawer and Jill Vickers (eds), Federalism, Feminism and Multilevel Governance, Farnham: Ashgate.

Dardanelli, Pablo, John Kincaid, Alan Fenna et al. (2019), 'Dynamic De/Centralization in Federations: Comparative Conclusions', Publius, 49 (1), Winter, 1-29.

Gibson, Edward L. (ed.) (2004), Federalism and Democracy in Latin America, Baltimore: Johns Hopkins Press.

Máiz, Ramos, N. Lagare and Pereira M. (2018), 'Catalonia: Federalism or Secession', Open Journal of Political Science, 8, 495-524.

Miller, Lisa (2008), The Perils of Federalism: Race, Poverty and the Politics of Crime Control, New York: Oxford University Press. 
Ng, Cecilia (2012), 'Gender and Governance: The Politics of Federalism in Malaysia', Kajian Malaysia, 30 (2), 1-26.

Przeworski, Adam, Michael E. Alvarez, Antonio Cheibub and Fenando Limongi (2000), Democracy and Development: Political Institutions and Well-Being in the World: 1950-1990, Cambridge: Cambridge University Press.

Ritter, Gretchen (2006), The Constitution as Social Design: Gender and Social Membership in the American Constitutional Order, Stanford: Stanford University Press.

Rubenstein, Kim (2006), 'Feminism and Federalism', address at the Gilbert and Tobin Annual Law Conference, February 24, accessed August 20, 2019 at https://law.anu.edu.au/sites/all/files/ 7 KimRubenstein.pdf

Sommer, Udi (2018), 'Women, Democracy and Politics: How Lower Fertility Rates Lead to Democracy', Demography, 55 (2), 559-86.

Vickers, Jill and Annette Isaac (2012), The Politics of Federalism: Canada, Australia and the United States, 2nd ed., Toronto: University of Toronto Press.

Watts, L. Ronald (2000), 'The Challenge of Federalism and Its Implications', in Yash Ghai (ed.), Autonomy and Ethnicity: Negotiating Competing Claims in Multi-ethnic States, Cambridge: Cambridge University Press, 29-52. 